\title{
Noise Complaints between Japanese Neighbors and Migrants in Rural Japan: From the Perspectives of Noisemakers
}

\author{
Median Mutiara \\ Graduate School of International Development, Nagoya University, Furo-cho, Chikusa-ku, Nagoya 464-8601, \\ Japan; median.mutiara@a.mbox.nagoya-u.ac.jp
}

Received: 1 September 2018; Accepted: 12 December 2018; Published: 17 December 2018

\begin{abstract}
This paper focuses on the narratives and embodiment of noisemakers in noise complaints in a small town of rural Japan. By building on the intersection of sound studies, body, and migration, this paper aims to critically address the longstanding concept of 'noise' through the overlooked perspectives of migrants who are perceived as 'noisemakers' in the neighbor relations between Japanese neighbors and migrants. This study was conducted through months of fieldwork in a small town in Japan, wherein an ethnic concentration of Japanese descendants from North Sulawesi, Indonesia has been established for almost two decades. Sensory ethnography was adopted in addition to participant observation and in-depth interviews that presented the narratives of five Japanese descendants working in seafood processing factories. The findings suggest that perception of the 'unwanted' bodily presence becomes a salient metaphorical sense of 'noise' which is embodied in migrants as byproducts of the psychological noise of the hearers. This 'noise' evokes series of complaints which also escalate into space control in the neighborhood. More than just neighbor relations in negotiating private-public spaces, the phenomena of noisemaking and noise complaints in this study are layered with overlapping unequal social and power structures concerning neighbors, workers, and migrants with stigma of gaijin and 'noisemakers'.
\end{abstract}

Keywords: noise; noisemakers; complaints; body; neighbor relations; migrants; Japan

\section{Introduction}

Noise can be subjectively related to how hearers discursively treat sound as noise (irrespective of its noise level), in that it depends on the hearers' attitudes, psychological states, and cultural perceptions (Augoyard and Torgue 2005) towards the noisemakers. Neighborhood noises, for example, include sounds with high information content, such as a (new) language, (foreign) music, or the noise of footsteps (Niemann et al. 2006). Even if the sound level is relatively low, some people tend to have their attention drawn to such informative sounds (Niemann et al. 2006). Complaining and blaming noise on certain groups of people from a lower social structure can escalate to boundary-making or space control. The sound produced by people with less social power (often addressed as "noise perpetrators") is often quickly judged as a noise disturbance by the sound hearers (often addressed as 'sufferers' or 'victims'). Through social structures and unequal distribution of power in neighborhoods, these two parties often represent the identities of 'us' and 'others', 'the sufferer' and 'the noisemaker', 'the majority' and 'the minority', 'the rich' and 'the poor', and the 'native' and 'the migrant'. For example, from the interview conducted with complaining neighbors by Stokoe and Wallwork (2003), the co-construction of 'us' and the 'other' identifies the ideology embedded in complaints about inappropriate movement and noise in domestic space. They argue that this discursive construction of groups functions as part of ongoing identity management and, in particular, contrasts how the normative 'us' and deviant 'them' 
are mobilized in talk (2003, p. 561). The overlooked and deviant 'other' is "a category of people who are not entitled to live with 'us' and should instead live in other places" (Ibid).

The previous studies indicate that the relationship between migrant and local neighbors in Japan underwent social and cultural difficulties. The difficulties of incorporating foreigners into Japanese society have been illustrated by the experience of the Brazilians (Tsuda 2003), the Koreans and the Chinese (De Carvalho 2003), and the Indonesians (Pudjiastuti 2005; Mutiara 2018). Pudjiastuti (2005) notes that the poor relations between migrants and Japanese neighbors in a rural town, Oarai, even resulted in the authoritative measures of a mass arrest of migrant workers in 2002, which was triggered by Japanese neighbors' complaints and reports on noise. A very recent work by Mutiara (2018) on the boundaries between factory work and church roles for migrants in Oarai also gives a glimpse of clue that neighbor conflict remains exists in contemporary Oarai. One participant in her work mentioned that her neighbors were "urusaii (noisy)," and "curious" of what her families do and wear (Mutiara 2018, p. 55). Through this paper, I want to discuss noise complaints in the neighbor relations between Japanese neighbors and migrants in Oarai, Japan, with some questions to ponder: What is perceived as noise in the neighbor relations between migrants and Japanese neighbors? What kinds of noise complaints persist in the present situation? How do they escalate and impact the migrants in their everyday situations? While much noise research focuses on the perspectives on noise hearers, this paper wants to give a spotlight to the silenced migrants who are attributed as 'noisemakers'.

\section{Background}

\subsection{Noise}

Noise has long been linked to pollution, disturbance, and violation in public and private spaces. Information theorists defined noise as "a signal that the sender does not want to transmit", while acoustical science interprets noise as undesirable sound (Plourde 2014, pp. 72-73). Noise sources discussed in the existing literature are comprised of public noise, produced by nonhuman objects or objects operated by human beings outdoors, and private noise, made by human beings and their interactions indoors. Research on public noise includes amplified sound (Dolan 2008), traffic noise (Aletta et al. 2018; Appleyard and Lintell 1971; Oku Okokon et al. 2015), environmental noise (Hiramatsu 1993; Jones et al. 1981), aircraft noise (McKennell 1963; Van Kamp et al. 2004), and industrial noise (Broadbent and Little 1960; Gloag 1980). In metropolitan cities or urban areas, such as New York City, surveys have found that most noise disturbances come from car horns, followed by car alarms, car stereos, and highway or street traffic (Bronzaft and Ryzin 2004). Studies on private noise include neighbor noise and complaints (Stokoe 2003, 2006; Stokoe and Hepburn 2005, Stokoe and Wallwork 2003), floor impact noise such as footsteps (Park and Lee 2017), privacy and neighbor noise in compact cities (Gurney 2000; Lindsay et al. 2010), and the health effects of loud neighbors and urban din (Weinhold 2015). Neighbor noise can contain a multitude of information about the activities of other human beings, which is different from the uniform sound of passing traffic.

In the abovementioned literature, discussions on the cause of noise disturbance are divided into two strands: first, those caused more by noise level, and second, those related to the subjective psychological conditions or noise sensitivity of the hearers. Noise level is a long-discussed topic in physical, health, and environmental studies, which usually focuses on the decibels of public noise and the health effects, attitudes, and beliefs of the hearers towards it (Jones et al. 1981). The downside of this type of study is the way sound is deliberately treated as noise for every individual, without a clear understanding that the same sound may not be perceived as 'noise' by everyone. Psychologists address this particular idea through their research on the noise sensitivity of hearers. They discuss the reactivity, vulnerability, and sensitivity of the individuals (hearers) to the source of noise (see Janssen and Vos 2011; Van Kamp et al. 2004). These studies found that individual differences are a more potent variable mediating the response to noise than is the level of noise per se (Jones et al. 1981, p. 45; McKennell 1963). Similarly, in relation to mental health, noise exposure per se may play only a 
minor role in the causal chain culminating in mental illness (Tarnopolsky et al. 1978). These results conclude that altering attitudes toward a noise source can significantly relieve community reactions to noise (Jones et al. 1981). Thus, many psychologists argue that it is problematic to claim that the effects of noise are due solely to the noise level itself. The abstracted points of these two strands are: first, no sound event can be isolated from the spatial and temporal conditions of its physical signal propagation; and second, sound is shaped subjectively depending on the auditory capacity, the attitude, the psychology, and the culture of the hearer (Augoyard and Torgue 2005). However, these two strands do not go beyond sound hearers, and thus overlook the social power of noisemaking and complaints in the neighborhood, such as social inequality and ethnic-racial prejudice. Hence, studies on neighbor noise with a focus on people attributed as noisemakers still demand attention (Petersen 2016).

In addition, from the philosophical point of view, noise can also be perceived as (bodily) presence. In his latest book, The Sonic Persona, An Anthropology of Sound, Schulze (2018) explains that noise can set in with a certain bodily felt sense (Gendlin 1992) and a corporeal tension (Nancy 2000, p. 126), making any situation or bit of practice imply much more than has ever been said (Gendlin 1992, p. 201). Such tensions are sensory articulations of a meaning, just before one might try to translate this bodily felt sense into action or words (Gendlin 1992). This is in line with Hankins (2014), who suggests that the reception of sound as noise is a practice that potentially involves the full body, rather than just one sensory mode, i.e., audition alone.

\subsection{Sound-to-Noisemaking and Noise Complaint}

From the literary review, the framework of sound-to-noisemaking and noise complaint is synthesized in Figure 1. It is shown that complaint is detached from noisemaking, as not all noise occurrence leads to complaints. Meanwhile, one of the determining factors of sound-to-noisemaking is the significance of the attribution given to those making the noise and their intentions by the ones hearing it (Levy-Leboyer and Naturel 1991). The main attributions listed in the figure are usually in binary: sound maker-sound hearer, noise hearer-noisemaker, complaint maker-complaint receiver. The noisemaker is the least-exposed subject in the studies of noise in the neighborhood contexts.

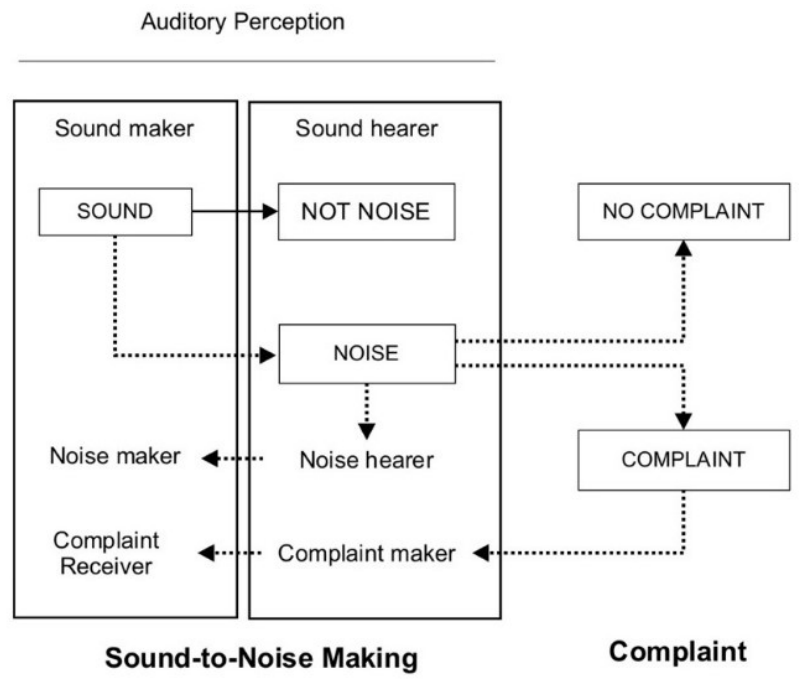

Figure 1. Framework of sound-to-noisemaking and noise complaint.

No sound is noise without the hearer's consent of transforming it into an 'unwanted' sound. The same type of sound can be perceived as noise or not depending on the sensitivity, attitude, and perception of the individuals hearing the sound. Thus, sound-making is a neutral event (in Figure 1 it is indicated by the solid arrow lines), while noise is never value-free (indicated by the dotted arrow lines). A noise is the unwanted sound which people call or treat as 'noise', within what kinds of activity 
noise occurs (Stokoe and Hepburn 2005), when and where the sound is heard as noise, and who makes the sound regarded as noise, and so on.

A complaint, on the other hand, is part of the verbal escalation (Johnson and Roloff 2000) for some hearers in response to noise. Some important factors to be noted from "noise" to "complaint" include which noise to complain about, who makes the complaint, and to whom, why, when, and how the complaint is made. Moreover, complaints are not a reliable index of noise disturbance, because only a small percentage of people exposed to noise suffer from it and actually complain (Levy-Leboyer and Naturel 1991). Thus, the arrow from "noise" can either go to "complaint" or "no complaint". The critical notion here is that the act of complaining can indicate a certain social power of the complaint-maker over the receiver ${ }^{1}$ (see Keizer 2010). The process of sound resulting in a complaint is, therefore, not solely related to the noise level, but is also based on the perception of the sound hearers, their motivation, and their social power (including access) to make a complaint.

Neighbor complaints are very complex because of the normative social order in neighbor relations. These unspoken norms of social life sometimes function quietly in the neighborhood (Stokoe 2006) and result in social discrimination. Frequently, this discrimination affects people's opportunities, wellbeing, and sense of agency (United Nations Department of Economic and Social Affairs 2018). The experience from multiethnic contexts shows that neighbor interactions and feelings of mutual trust can help to remove social barriers between majority and minority groups and foster social cohesion (Alesina and La Ferrara 2002).

\subsection{Noise Complaints and Neighbor-Migrant Relations in Japan}

Japan is often regarded as an oto zuke shakai (sound-saturated society), as in the public spaces of urban Japan, one's every movement is mediated through sound (Plourde 2014, p. 71). It is also propounded by an author of a series of books about noise in Japan, Nakajima, that "most Japanese people don't see 'noise' as a problem, and a large percentage of them actually want this 'noise'" (in Krieger 2014). Sound, in Plourde's work, refers to melodies and musical instruments, while noise in Nakajima's book refers to the loud sound of public loudspeakers. Both works explain the receptivity of Japanese people towards public noise. According to Dolan (2008), Japanese people are significantly less annoyed by sounds encountered daily than are Americans and are less than half as likely as Americans to complain directly to neighbors perceived to be noisy. However, he mentions that the results may be influenced by the reticence of Japanese study participants to complain about noise. Hence, the concept of noise disturbance and complaints, especially regarding private noise in the neighborhood in Japan, are still interesting questions for future research (Dolan 2008).

In fact, the previous studies indicate that the relationship between migrant and local neighbors in Japan often suffers from discrimination, prejudice, and hostility, and both groups of neighborhood residents are more reliant on social networks with fellow in-group members (Chen et al. 2011; Roberts 2002). The difficulties of incorporating foreigners into Japanese society have been illustrated by the experience of the Koreans and the Chinese (De Carvalho 2003). The segregation and neighbor interaction of Nikkeijin and the local Japanese in Tsuda (2000) work for Brazilian Nikkeijin in Toyama, for instance, is important to understand the nature of neighbor relations between migrants, especially Nikkeijin and locals in Japanese society. In his observation, most of the Nikkeijin do not actively seek out relationships with the Japanese, mainly because the Japanese do not seek out relationships with them, thus exacerbating the social distance between the two ethnic groups (Tsuda 2000, p. 12). He also claims that Brazilians are more socially reluctant than the Japanese, which is arguably due to their acute consciousness of Japanese ethnic expectations and a resulting sense of cultural inadequacy.

1 When noise hearers decide to make a complaint, their attribution is listed as a complaint-maker. At the same time, if the noisemakers receive a complaint, their attribution becomes a complaint-receiver. I will use these terms to refer to the events and the actors or to emphasize which event is currently being discussed. 
Meanwhile, relations between Indonesian migrants and local Japanese in Oarai, Ibaraki are briefly mentioned in a few previous studies (Pudjiastuti 2005; Sumakul 2005; Tirtosudarmo 2005). Pudjiastuti (2005) notes the poor relations between migrants and neighbors, which results in authoritative measures. She stated that there was a mass arrest of overstaying Indonesian workers in 2002, which was triggered not by immigration authorities or the police, but by Japanese neighbors who became impatient about car accidents, noise, and other disturbances caused by the workers. Consequently, police officers conducted patrols many times per day and posted notices on the walls of apartment buildings where many Indonesians were living (Pudjiastuti 2005, p. 96). Additionally, the characteristics of local Japanese in Oarai are pointed out through the statement of a Japanese pastor of a church in Mito ${ }^{2}$ in Sumakul (2005) dissertation, stating that the local people in Oarai prefer to live in a close community with no interaction with urban people and that they are resistant towards foreigners living in their neighborhood. Indeed, the potential threat of racism is more difficult to escape in rural areas than in urban ones (Pugh 2007 in Danson and Jentch 2012). At the same time, the 'Minahasan ${ }^{3}$ community' in Oarai becomes "a closed community", due to their majority visa status as undocumented migrants, or as he believes, similar to "a ghetto" (Sumakul 2005, p. 178). Moreover, Tirtosudarmo (2005) states the importance of neighbor relations through the Indonesian pastor's guidance at the church ${ }^{4}$, recommending that the workers avoid committing theft, adultery, or excessive drinking, and that they establish a positive rapport with the Japanese and their other neighbors.

These studies from the early 2000s offer a glimpse into past migrant and neighbor relations in Oarai. Nevertheless, these studies were conducted almost 15 years ago, when overstaying migrants outnumbered the legal ones. Meanwhile, from 1998 to 2005, there were mass arrests of nearly three-quarters of the overstaying migrants in Oarai. Thus, the landscape of migrants has since changed drastically, especially after the arrival of more generations of Japanese descendants from North Sulawesi in the late 2000s. Additionally, varying types of visas for foreigners have been introduced since then, such as trainees (kensushei), students of the Japanese language courses, and more recently, refugees (namin). However, part of the picture in migrant-neighbor relations remains hidden in existing works, as we do not have sufficient information on those people who are attributed as 'noisemakers' and subjected to noise complaints. Habituation to noise is an important topic to consider, as this appears to be largely independent of self-reported noise sensitivity rather than objective reports (Smith 2003), especially from people attributed to noise.

\subsection{Migration in Rural Oarai}

The first arrival of foreign nationals of Japanese descent to Japan was initially triggered by the reform of Immigration Law in June 1990. At that time, the number of Japanese descendants was projected to fit the needs of a "temporary" labor shortage as well as to solve the agitation of impurity in Japanese ethnic, social, and institutional reconfiguration. Among Japanese descendants scattered around the world, Brazilian Nikkeijin ${ }^{5}$ were considered to be the priority in confining the criteria of temporary compared to Nikkeijin from Asian countries (see Tsuda 1999). This new law changed the admission status and created a clear classification of immigrants by their statuses, which closely corresponded to ethno-racial categorical lines (Shin 2010). Although the arrival of Nikkeijin was projected to be just temporary regarding time, in reality, the population of Brazilian Nikkeijin is growing, and is followed by the other counterparts from the Philippines subsequently to the acute labor shortage in the 3-D (dirty, dangerous, demeaning) type of jobs. A high population of migrants,

2 Mito is the capital of Ibaraki Prefecture, which is located approximately $11 \mathrm{~km}$ from Oarai. The pastors of this church in Mito often assist the congregation of an Indonesian church in Oarai with ecclesiastical matters.

3 In Sumakul's study, he uses the term 'Minahasan' to address the ethnicity of Indonesian migrants from North Sulawesi in Oarai.

4 The church is an ethnic church with all Indonesian members and pastors.

5 Nikkeijin in general refers to Japanese descendants who live outside Japan. 
including Japanese descendants, commonly live and work in industrial cities in Japan. Based on the Statistics on Foreign Residents Registered by Ministry of Justice (2015), the highest concentrations for Japanese Brazilians are located in industrial areas in Shizuoka, Mie, and Aichi Prefectures ${ }^{6}$.

In Ibaraki Prefecture, around $100 \mathrm{~km}$ from the northeastern part of Tokyo, there is a distinct concentration of Japanese descendants and migrants from North Sulawesi, Indonesia, in a small town called Oarai ${ }^{7}$. This town has a population of about 16,000 and covers an area of only $23.7 \mathrm{~km}^{2}$, comprising three villages-Ishohama, Oonuki, and Natsumi. In Oarai, the Japanese descendants from North Sulawesi mostly originate from three cities: Manado, Tomohon, and Bitung. They started entering Japan in the late 1990s, while the Brazilian and Filipino Nikkeijin have entered Japan since the 1980s and 1990s, respectively. The trajectory of Nikkeijin from North Sulawesi to Oarai began when a broker, who was also the chief of a factory association in Oarai, came to Sulawesi after learning that there were many Japanese descendants in North Sulawesi. From 1998 to 2005, a total of 180 Japanese descendants from North Sulawesi were moved to Oarai (Meguro 2005). All of their registries and documents were arranged by the broker. Their apartment to live was also set up by him; thus, in the first years of migration, the Nikkeijin did not interact directly with the local people (Mutiara 2018).

Most of the Indonesian migrants in Oarai work in the fish and seafood industries as low-skilled laborers, or otherwise in agriculture and construction. The fish industry in Oarai is distinctive from other cities. As early as the mid-1960s, it actively introduced and utilized imported seafood and had reduced its dependence on the unstable local fisheries, thereby establishing a year-round operation (Meguro 2005). Whereas others focus on producing high-quality dried mackerels by manually processing domestic horse mackerels, Oarai's processors specialize in making lower-priced products with the use of imported raw materials, a fish-cutting machine, and a low-skilled workforce (Honda and Ono 2000). Oarai is a unique case, as Nikkeijin workers from Indonesia make up a large part of the seafood-processing migrant workers in the town (Meguro 2005). Although the fishing port is not among the largest in Japan, seafood processing is the dominant local industry. Additionally, among fish-processing industries in Japan, the percentage of international migrants working in Oarai is among the highest (Mazumi 2014) ${ }^{8}$. According to Meguro (2010), Oarai has experienced frequent shifts in the numbers of foreigners: in 1985, Iranian migrants dominated, followed by Filipinos and Thais. From the information of one of the participants who moved to Oarai for the first time, before the Nikkeijin coming from North Sulawesi, in 1992, a small number of overstaying Indonesian migrants working in Tokyo started coming to the town following the information from their networks. After the first Nikkeijin came in 1998, Indonesian people began to outnumber migrants from other countries living in Oarai $^{9}$ (See Figure 2). This only occurs in Oarai; in other cities in Japan, the population of Chinese, Korean, Filipino or Brazilian migrants usually dominates.

Rural areas, such as Oarai, are usually perceived as somewhat disconnected and isolated from international migrants and minority ethnic groups, which are understood as largely urban phenomena (De Lima 2012). However, rural areas and populations do not exist in a vacuum. In the field site investigated in the present study in Oarai, Japan, the restructuring of rural economies, the impact of globalization, demographic change (e.g., a declining and aging population), and the out-migration of young people (De Lima and Wright 2009) precisely describe what factors have been significant drivers of change.

6 For research on Brazilian Nikkeijin in Hamamatsu, see Sugino (2008); in Toyota, see Linger (2001); and in Toyama, see Tsuda (2000).

7 Besides the abovementioned prefectures, there is another concentration of Japanese Brazilian in a small town, Oizumi, Gunma prefecture (see De Carvalho 2003), which is similar to the case of Oarai.

8 For more about local fisheries in Oarai and Japan, see Meguro (2005), Honda and Honda and Ono (2000), and Mazumi (2014).

9 As of April 2005, Indonesians were the largest group of foreigners, with 443 people, followed by Chinese (154), Filipinos (112), Thais (58), and Brazilians (25), according to Oarai's foreigner registration documents (Meguro 2005). 


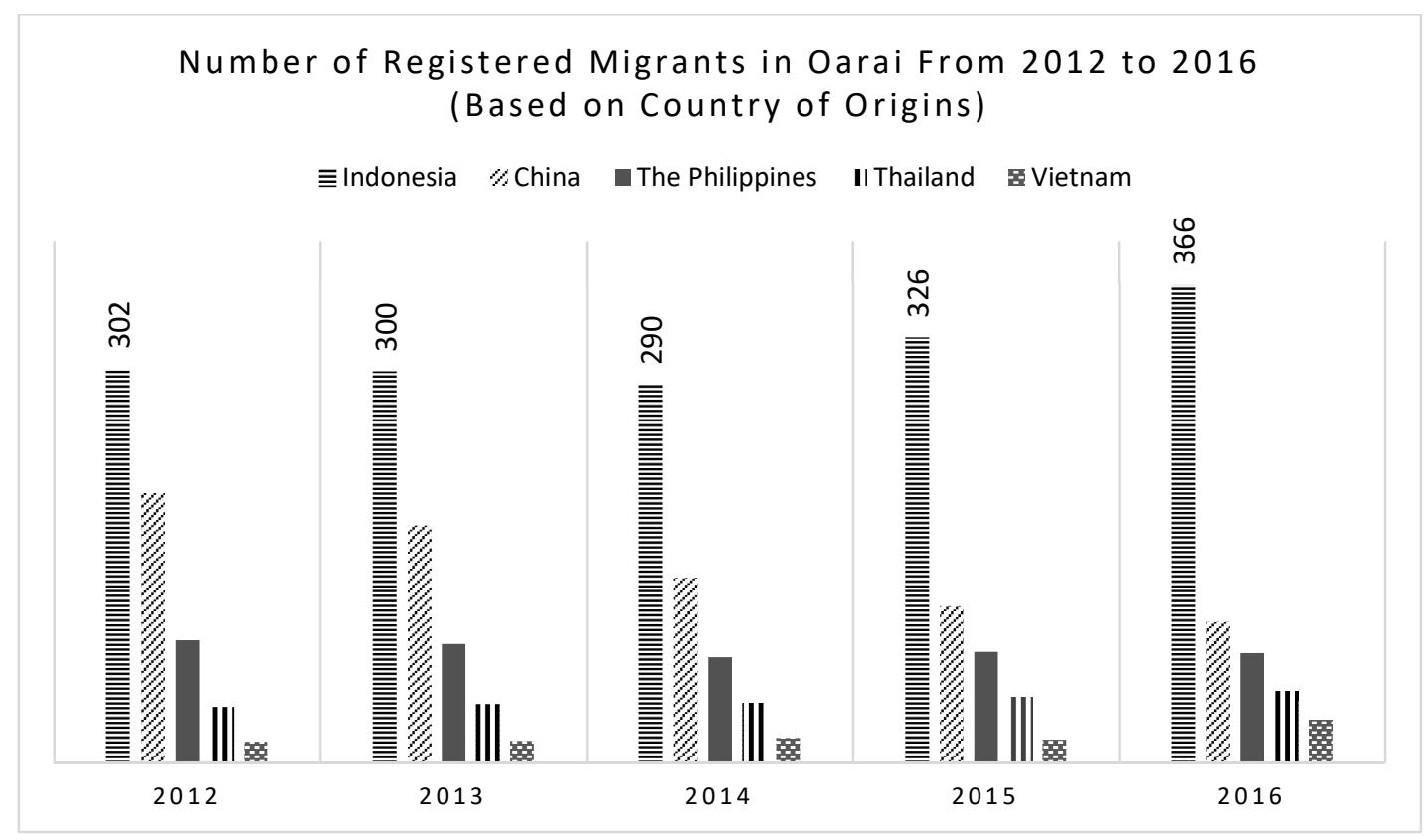

Figure 2. Number of registered migrants in Oarai from 2012 to 2016 by country of origin. (Data source: from a personal request to Oarai Town Office in 2018, graph by author.).

\section{Research Methods and Settings}

\subsection{Participants and Settings}

I conducted preliminary research in Oarai, Japan, between February and March 2016 and in Manado and Tomohon, North Sulawesi, in January 2017. After some planning and preparation, I lived in the neighborhood from April to November 2017. The study's participants were migrant workers and their families from North Sulawesi, Indonesia, comprising 50 adults and 14 teenagers $(n=64)$ in 32 households. The study participants mainly lived in the Ishohama area, in apaato or old houses owned by the company they currently worked for or used to work for (see Table 1). An apaato ${ }^{10}$ (アパート) is the Japanese term for a two-story apartment building that is usually small and made of wood. Similar to the old land houses, due to their wooden structure, the buildings' soundproofing tends to be weaker than that of mansion apartments, which are made of concrete with three or more floors. There are only a few mansion buildings in Oarai. One of them is the complex of old juutaku (住宅)—buildings or municipal public housing—which are located in the lowland, near the seashore. Among the study participants, four families live in the concrete mansions, while another four families choose to share the space with their relatives or other migrants to make the rent more affordable.

Table 1. Housing types and ownerships in which the participants (by households) live.

\begin{tabular}{ccccc}
\hline \multirow{2}{*}{ Ownership } & \multicolumn{4}{c}{ Housing Types } \\
\cline { 2 - 5 } & Single House & Shared House & Apaato & Mansion \\
\hline Company Relation & 7 & 4 & 12 & 0 \\
No Company & 2 & 0 & 2 & 2 \\
Relation & 1 & 0 & 0 & 0 \\
Self & 0 & 0 & 0 & 2 \\
Municipal & &
\end{tabular}

10 Most participants pronounced it as "aparto". 
In this paper, five stories from five participants (from five different households) with their neighbor experiences are presented (see Table 2). The reasons for choosing five participants are because of the limited space in this paper and because they deliberately expressed their compelling experiences and emotions regarding their relations with their neighbors. In the case of Karinda, Denna, Priscilla, and Bella, I also had a chance to experience with them how they made compromises in some situations because of their neighbors. For Leo, I had a chance to see and experience his hospitality in serving customers in the shop where he works. All of the participants are given pseudonyms to ensure their anonymity: Karinda, Priscilla, Bella, Dena (all female), and Leo (male). I met most participants for the first time in 2016 at churches and religious liturgies during my preliminary research. Dena was interviewed in both 2016 and 2017; however, she did not discuss her neighbor in the first interview. Karinda and Bella were interviewed in 2017, and Priscilla and Leo were interviewed in 2016. The five participants in this paper lived in old land houses (Karinda, Dena), apaato (Bella, Leo), and a shared house (Priscilla). 
Table 2. Five participants' profiles.

\begin{tabular}{|c|c|c|c|c|c|c|c|c|c|}
\hline $\begin{array}{c}\text { Name } \\
\text { (Pseudonym) }\end{array}$ & Sex & Age & $\begin{array}{c}\text { Last } \\
\text { Education }\end{array}$ & $\begin{array}{l}\text { Japanese } \\
\text { Generation }\end{array}$ & First Arrival & Current Work & Japanese Fluency & $\begin{array}{l}\text { Type of } \\
\text { Housing }\end{array}$ & $\begin{array}{l}\text { Owner of the } \\
\text { House/Apaato }\end{array}$ \\
\hline Priscilla & $\mathrm{F}$ & $50 \mathrm{~s}$ & $\begin{array}{l}\text { High } \\
\text { school }\end{array}$ & The 3rd & 1998 & $\begin{array}{l}\text { worker of } \\
\text { Kaisha A }\end{array}$ & $\begin{array}{l}\text { - Speaks work-related/simple } \\
\text { conversational Japanese }\end{array}$ & Shared House & Kaisha A \\
\hline Leo & $\mathrm{M}$ & $40 \mathrm{~s}$ & $\begin{array}{l}\text { High } \\
\text { school }\end{array}$ & $\begin{array}{l}\text { Spouse of } \\
\text { the 3rd }\end{array}$ & 2000 & $\begin{array}{l}\text { worker of } \\
\text { Kaisha B }\end{array}$ & $\begin{array}{l}\text { - Speaks work-related/moderate } \\
\text { conversational Japanese } \\
\text { - Reads simple hiragana and kanji }\end{array}$ & Apaato & Kaisha B \\
\hline Denna & $\mathrm{F}$ & $30 \mathrm{~s}$ & University & The 3rd & 2005 & $\begin{array}{l}\text { worker of } \\
\text { Kaisha C }\end{array}$ & $\begin{array}{l}\text { - Speaks work-related/moderate } \\
\text { conversational Japanese } \\
\text { - Reads and writes hiragana }\end{array}$ & House & Kaisha C \\
\hline Karinda & $\mathrm{F}$ & $40 \mathrm{~s}$ & $\begin{array}{l}\text { High } \\
\text { school }\end{array}$ & The 3rd & 2001 & $\begin{array}{l}\text { worker of } \\
\text { Kaisha C }\end{array}$ & $\begin{array}{l}\text { - Speaks work-related/moderate } \\
\text { conversational Japanese }\end{array}$ & House & Kaisha C \\
\hline Bella & $\mathrm{F}$ & $40 \mathrm{~s}$ & University & The 3rd & 2002 & $\begin{array}{l}\text { worker of } \\
\text { Kaisha D }\end{array}$ & $\begin{array}{l}\text { - Speaks work-related/moderate } \\
\text { conversational Japanese }\end{array}$ & House & $\begin{array}{l}\text { Kaisha E (where } \\
\text { she used to work) }\end{array}$ \\
\hline
\end{tabular}




\subsection{Methods}

The methods used to perform data collection were interviews, participant observation, and sensory ethnography. Some life events that I engaged with the participants are Sunday liturgy, church anniversaries, wedding ceremony, funeral, birthday parties, and other daily activities such as grocery shopping, meeting people, going to clinics and so on. I also had a chance to work in one factory. Conversations took place at home, while cooking, dining, or cleaning, or in the car or at the churches. Although I had a topic list in hand and a personal information list to fill in, the interviews prompted natural storytelling regarding participants' lives, starting from their premigration journey and moving from the past to the future. These included the participants' memories of life before migration, their first years in Japan, a typical work day, their challenges, their family matters, and their future plans. The language used was Bahasa Indonesian mixed with Bahasa Manado ${ }^{11}$ and Japanese. The participants' Japanese language skills were very minimal, despite living in Japan for more than 15 years. They only learned from what they heard in the kaisha (company/factory). Therefore, their Japanese words were often not accurate in their pronunciation and grammar ${ }^{12}$.

Although the participants were familiar with my presence as someone residing in Oarai and attending the liturgies, they participated voluntarily and were well-informed about my role as a researcher via a letter of consent and details of my study. They were always able to indicate any information they wanted to exclude and to stop participating at any time. All interviews were digitally recorded and transcribed verbatim, and the transcripts were read through several times. The details of the study and consent letter were also sent to the assembly of the church for permission and consent from the pastors. I was also given time to introduce myself at the church for my study purposes.

Issues relating to neighbors came up in many participants' narratives when they explained the challenges of living in Japan. However, the narratives alone cannot vividly portray their feelings on neighbor relations in close proximity. Emotions such as ambivalence, shame, and guilt are not usually captured easily through narration; they must be felt and experienced by the researcher to be understood (Rivera and Tracy 2014) via the body and thus the senses (Sunderland et al. 2012). Furthermore, Goffman (2001) asserts that the body in participant observation is an important way to gain "data", because you "subject yourself, your own body [ ... ] to the set of contingencies that play upon a set of individuals" (Goffman 2001, p. 154). I began to experience being a migrant worker and making relations with Japanese neighbors in 2017 when I lived in a rented apaato in the Oarai neighborhood and worked in a kaisha. I became the neighbor of the study participants, experienced being the neighbor of Japanese and the non-Japanese people, and experienced various sensory engagements and practices on-the-go with the participants in the neighborhood. These sensory engagements included the daily practices of neighboring, such as greeting my neighbors, turning the lights on or off on the patio for public light, throwing the garbage out at the scheduled time, sharing food, borrowing tools, and learning the 'dos' and 'don'ts' in the neighborhood. Other than neighboring activities, I also participated in many of the daily activities of migrants, which I have mentioned earlier, such as shopping, recreation, gathering, cooking and participating in their events. By paying attention to the multivocality of a particular sensory experience, sound and various meanings encapsulated within the sensory experiences of events and spaces can be more wholly explored and analyzed (Ricke 2017).

11 Bahasa Manado is the North Sulawesi people's colloquial language (Manado itself is the name of capital of North Sulawesi). The language diction is absorbed from Malay, Dutch, Japanese, and Spanish as a result of the colonial history in Celebes (the previous name of Sulawesi).

12 I learned the process of how migrants started acquiring Japanese language from newcomer refugees in Oarai who asked me to teach them Japanese. 


\section{Findings}

Nikkeijin from North Sulawesi started to come to Oarai in 1998 without making a deliberate choice to work. They were placed in dirty, dangerous, and demanding jobs in seafood-processing factories. These jobs involved cleaning fish over long and tiring working hours and came with the risk of accidents when cutting the fish through a machine (one worker I interviewed lost one of their fingers). Most workers left more stable office jobs in North Sulawesi that had lower income compared to their demanding 'part-time' jobs in Japan. In the first years, they were also placed to stay in a cramped apartment owned by the broker. According to the participants, their first apartment was old and indecent: there was only one toilet, one bathroom, and one kitchen for ten families in ten small rooms. Two years after their initial arrival in Oarai, more migrant workers invited their children to come. They started looking for other apartments with more decent conditions for their families. However, renting an apartment in Japan is often hard for foreigners because they are required to have a Japanese guarantor. Consequently, most workers usually just move to an apartment owned by their kaisha, which is located near their place of work. The five participants' whose stories appear in this paper lived some hundred meters away from each other.

\subsection{Priscilla and Barbed Wire}

During the pre-research in 2016, I stayed at Priscilla's house for two weeks. The building, which is quite old, is owned by a shachou (owner of a factory or a company) where she works. Priscilla lived there with her extended family and was one of the coordinators of the house, as entrusted by the kaisha owner. The building was originally a house with a store under one roof. It comprises two parts: the house on the back side and a large garage at the front (in the past, it was used as a store), which was used by Priscilla's family as a multifunctional space. Both parts are separated by a curtain, but it is always left opened. The entrance to this house is through the garage. Therefore, the doorway is not so close to the house part. The house comprises two stories, five bedrooms, two bathrooms, and one big kitchen with two cooking stations. The house interior is made of wood, with outdated parquet flooring outside the rooms and loosened tatami flooring inside the bedrooms. Three bedrooms are located on the second floor, while the two others are on the first floor, opposing the kitchen. I stayed in the room closest to the kitchen.

Every morning at around 6 a.m., everyone in the house rushed to go to work. The women prepared lunch boxes for themselves and their families, and no one stayed at home. At noon, a couple of residents returned for a short lunch and then went back to work. At around 7 p.m., everyone came home tired. While the men cleaned themselves up, the women prepared dinner for their own families. The families took turns using the four-seat dining table. The inviting smell of richly flavored spicy cuisine emanated from their kitchen. However, the kitchen was not bustling for long. After finishing their dinner, the women took a bath and everyone went to their own rooms to watch TV, check and interact on social media, or contact their children or parents in Indonesia. This was more or less the daily routine and family interactions at home. My observations confirmed their assertions that they barely talked with or met the other family members, although living in the same house.

However, I was struck by the barbed wire and a hand-written sign in English reading "Stop that racket" facing into the entrance door of the door (see Figure 3), from where I could also see the neighbors' wall and gap amongst the houses. The migrant's house does not share a wall with the neighboring houses, and there is a one-meter pathway between the walls. When I asked Priscilla's brother, who also lived there, about the sign, he explained it briefly in a relaxed manner: "Oh, it has been there for a while, because our neighbor is urusaii (noisy), so mama-san (the wife of shachou) was angry and put the sign. We don't know what it means, though. What is 'racket'? We don't understand [its meaning].". It was surprising to see the sign and the wires, which made it appear like a "no trespassing" sign for animals. In Priscilla's brother's understanding, mama-san put up the sign for the neighbor, not for him and his families. He said that mama-san was angry at the neighbor 
because the latter was urusaii. Priscilla's brother did not see this sign as an offense to him because of this understanding and not understanding the meaning of 'racket'.

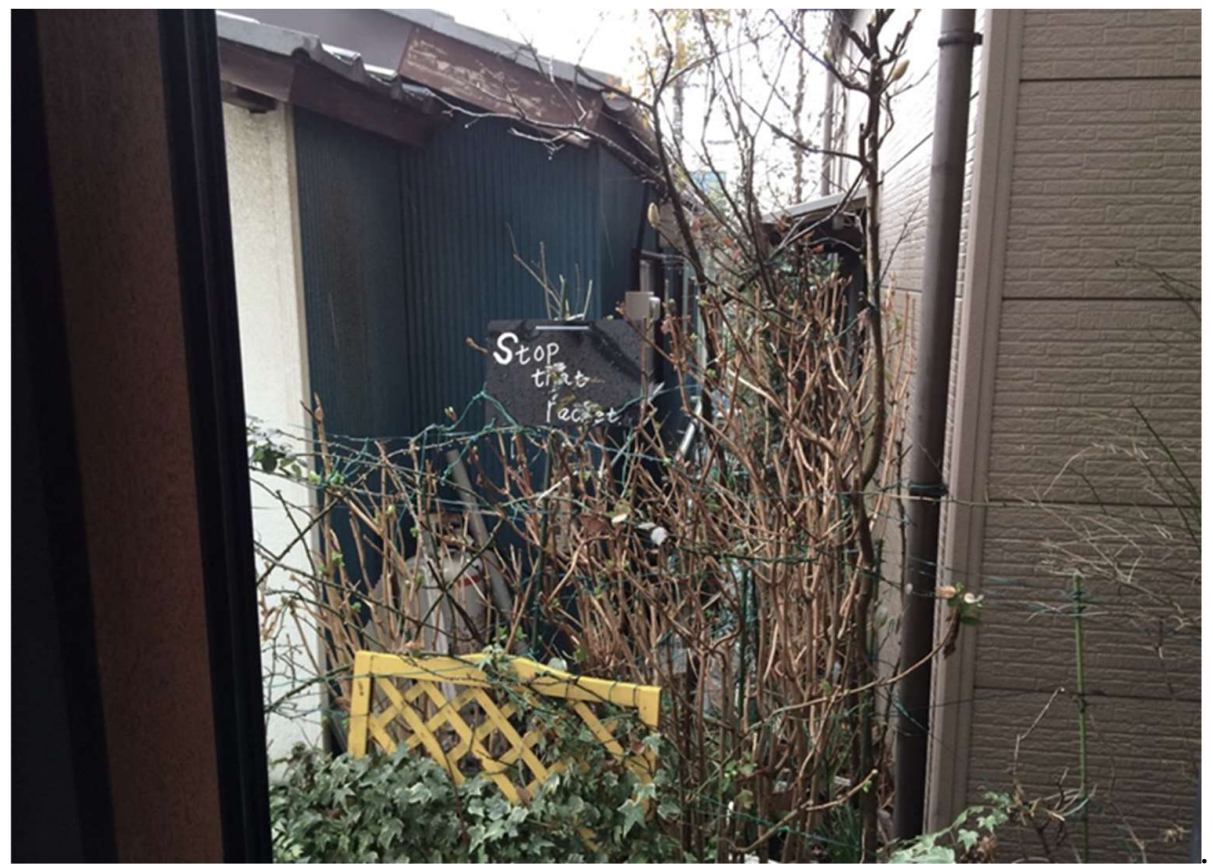

Figure 3. The sign and barbed wire in front of the door of the Indonesian migrants' apartment.

When I interviewed Priscilla in the house's living room, she had a chance to talk about this neighbor:

"Japanese people don't like if we are noisy. Well, it is the same thing as people in our kampung $^{13}$. [They] also don't like if we are noisy, right? Japanese people after 9 p.m. want to go to sleep. That is their sleeping time, resting time." (in a very calm tone).

"How 'noisy'?" I asked. Still with the same calm tone, Priscilla continued:

“There are some ... people who talk too loudly. Some neighbors might get used to these, but some others have not. They cannot. Just like neighbors in front of that door." She indicated the doorway on my opposite.

Priscilla talked in a very calm manner and did not sound emotional during the interview. She tried to understand how Japanese people are. She put herself in the position of Japanese people in Oarai, like "people in our kampung" who also do not like noise. Oarai is portrayed as the kampung for her. Her defining of 'noisy' lies in how others, in this case, neighbors, perceive loudness. She admitted that some people in the house might talk too loudly, but the perception of being noisy is not about the loudness of the noise itself, but rather about how loud others think it is. She further described the sound her family had made which triggered her neighbor's anger.

"In the past, when I just climbed the stairs, the oma ${ }^{14}$ (the neighbor) knocked the walls."

Priscilla knocked the table to illustrate.

13 A kampung (Bahasa Indonesian) is a group of houses which are part of the city (usually inhabited by low-income people); village; hamlet; the smallest administrative unit occupying a certain area, located under the subdistrict level; a backward (not modern) place; related to habits in the village; old-fashioned; page of the area or village of birth (based on Kamus Besar Bahasa Indonesian online).

14 Oma (Bahasa Indonesian/Bahasa Manado) is grandmother. 
““Aa, noisy!" She (the neighbor) shouted." Priscilla illustrated it in a whisper.

She lowered her tone and sounded a little apprehensive. "Then, I wondered, what should I do; I only want to walk in the house? I cannot walk or climb the stairs ... it always makes a sound. What should I do?"

The house's floor, as it is an old parquet, always makes a sound when walked upon. When I stayed in her house, I also had to step slowly at night to avoid making any creaking sounds that could disturb anyone in the house. Priscilla's room is on the second floor, so whenever she wants to go to her room, she has to climb the stairs, and a creaking sound is inevitable. However, the level of sound is barely audible outside the building. Moreover, the neighbor's wall is not adjacent to Priscilla's house. Priscilla, who only does what people typically to do at home, finds it puzzling how it could be heard as noise by her neighbor.

"One day, the oma was angry. She wanted to call the policeman. "I want to call the policeman", she said. Then I said, "Yes, it's fine if you want to call the policeman, we don't make any keributan ${ }^{15}$. We only talked in the house. We don't make any keributan." Then she went back to her house ..."

Priscilla lowered her voice until I could not even hear her, but I could feel her sadness and desperation. She answered her neighbor's complaint with "any Japanese words coming out from her mouth.". She admitted that she actually could not speak Japanese.

"So, did she call the policeman?" I asked.

"No, maybe (at first) she thought we were migrants without staying permission."

Noise for Priscilla is disturbance, like doing something out loud and beyond the scope of quotidian activities at home. Hence, she did not find it reasonable when the neighbor complained about the sound she made when climbing the stairs or talking with the other family members. For Priscilla, it is possible that the neighbor did not report the 'noise' to the policeman because she may have found that Priscilla and her families were not overstaying migrants. Many other dialogues also showed that when neighbors threatened these migrant workers with reporting them to the policemen, the latter were not afraid as they had a valid visa. In fact, their neighbors never really reported them to police officers, but rather reported them to the owner of the house. The owner of the house, who is also the owner of the kaisha, usually chooses to mediate the conflict, but asks the migrants to concede or to be patient with their Japanese neighbors. It is mama-san, instead of the shachou himself, who usually handles the social issues among the tenants (who are also the workers of the kaisha), such as what happened to Priscilla.

\subsection{Bella and X-Chan}

Bella lives with her family about one-and-a-half kilometers from Priscilla's house. I lived only $100 \mathrm{~m}$ from her house. For the interview, Bella came to my house, as it is almost impossible for anyone to visit her house, even her relatives, due to the illogical sensitivity of her next-door neighbor to sounds. The relation with this neighbor has thoroughly influenced Bella's family life. Not only does she always have to avoid having a guest or making phone calls at home, but her daughter also suffers from unhealthy daily oppression and conflicts with this neighbor. Bella even had to rearrange the interior layout of her house, such as moving her TV and rearranging her guest room and dining room. Rooms where she and her family spend more time interacting are rearranged far away from the shared wall

15 Keributan (Bahasa Indonesian) is disturbance. 
with her neighbor. Additionally, Bella and her family never eat in the dining room, but rather in the kitchen, the farthest room from the wall. Everything she does is to avoid making sound. For instance, when answering a phone call, she always whispers, and answers it in the kitchen. When the connection is not stable with her family in Indonesia, she has to go outside and sit in the car or go to the nearest drug store's parking lot.

During our talk, Bella cheerfully told me the story about how her family and Indonesian friends helped each other to renovate the interior of their house when she first moved there. She was glad about such renovation, and her teenage daughter had her own room. When continuing, suddenly, her tone changed. She sighed, and said:

“But the only mondai (problem) is that person, X-chan. He didn't behave that way before. We don't know what happened to him. Was there someone hating us that told X-chan ${ }^{16}$ something, so he changed his behavior? He just suddenly changed. Suddenly, he was so angry. When we just talked like this, he hit that wall.... In the past, he was fine. We even held a liturgy at home every Saturday, Tuesday, Friday. There was no problem when he had just moved in. [ ... ] Before him, it was a Peruvian family living there. They also had no problem."

Bella's house, unlike Priscilla's, shares a wall with her neighbor. In January 2017, she had a big quarrel with this neighbor, X-chan, a Japanese man in his thirties. The man came to Bella's front door after hearing an infant crying in Bella's house on Sunday's afternoon. The infant is Bella's niece, who did not usually come inside Bella's house, but had done so because she needed to go to the toilet. The man accused her of always being noisy, including holding a loud party at her house during New Year's Eve. He also threatened her to report this to the shachou. Bella was astounded by the accusation because she and her family were out of town during that time. They then had a quarrel outside Bella's house. Bella responded in soliloquies for almost the entire interview, vividly depicting the situation when talking about her conflicts:

"We said to him: "You are the one who gets noisy. You are noisy with your cat. [ . . ] You knocked the walls. You often do this (knocked the table). Later we will record it. We will report you to the policeman." [ ... ] It is because he easily reports to shachou ... We challenged him, "You report to shachou, we will report to policemen." (Then) He said, "Douzo-douzo (go ahead), report to the policemen. I am sure you yourself are afraid because you are just gaijin (foreigner)." We said, "No, we are not afraid. You want us to report you now? You want us to call the policemen now? Want now?" He was silent."

On that day, the Japanese man reported his complaint to shachou, then mama-san came to mediate. In the end, Bella's family volunteered to apologize for any noise they may have made which had disturbed the neighbor. Mama-san then urged him to apologize too; however, despite this pressure, he did not want to apologize. On another day, Bella also apologized to the shachou for this problem. He just asked Bella to be patient.

Bella said that X-chan lives in the house alone, but often tortures his cat by throwing something at it, thumping, and making other banging noises. She also often hears the crying cat and the man yelling at something. The sound the Japanese man makes is also considered as noise for Bella and her family, as the sound is outside what is common for them to hear at home. However, she always tried to ignore it, until the Japanese man was outraged in front of her door because of her niece's one-time crying. Bella realized that although she is a Japanese descendant, this Japanese man always sees her as merely 'gaijin'. Gaijin is a compelling word, which is stigmatic when it comes to Indonesian-Japanese

16 In Japanese, -chan is usually used to address children or a younger person. The Japanese man is called with -chan by the shachou, and this is how Bella addressed him too. 
descendants in Oarai. Although they have blood ties with the Japanese, other than having legal visa status, Indonesian migrants do not enjoy any privilege in the society. They are still gaijin for most Japanese.

\subsection{My Interactions in the Neighborhood}

My interactions with the surrounding Japanese neighbors (and how they interacted with me) were minimal, limited to only standard greetings, to a few people who wanted to interact with me. For instance, when X-chan and I passed each other, although I nodded and smiled, he always looked away. It happened that way until the end of my stay. My next-door neighbor also never replied to my greetings, despite my active initiation saying: "konnichiwa" (good afternoon). Only one elderly Japanese woman living next to Bella who nodded and replied back to my greetings. We often met, as she always called up her cat around the neighborhood. Yet, we never had a real conversation. This is how neighbor relations happened in my surroundings. This made me feel much closer with the Indonesian migrant community.

The kaisha owning the complex was about $150 \mathrm{~m}$ from my rented apaato (see Figure 4). Hence, the complex of apaato was meant to be rented for the kaisha's workers ${ }^{17}$. It was my first time living in an apaato in Japan; I used to live in a mansion. My first impression was that there was no privacy or secure feeling: the front door was the only border from public to my private space; conversely, in a mansion, there is a pathway for the residence outside the door with a 24-h security and a locking system in the building. The other side of this apaato, the windows, is also connected to the public space with no boundaries. Thus, public noise intrudes easily into the apaato and vice versa.

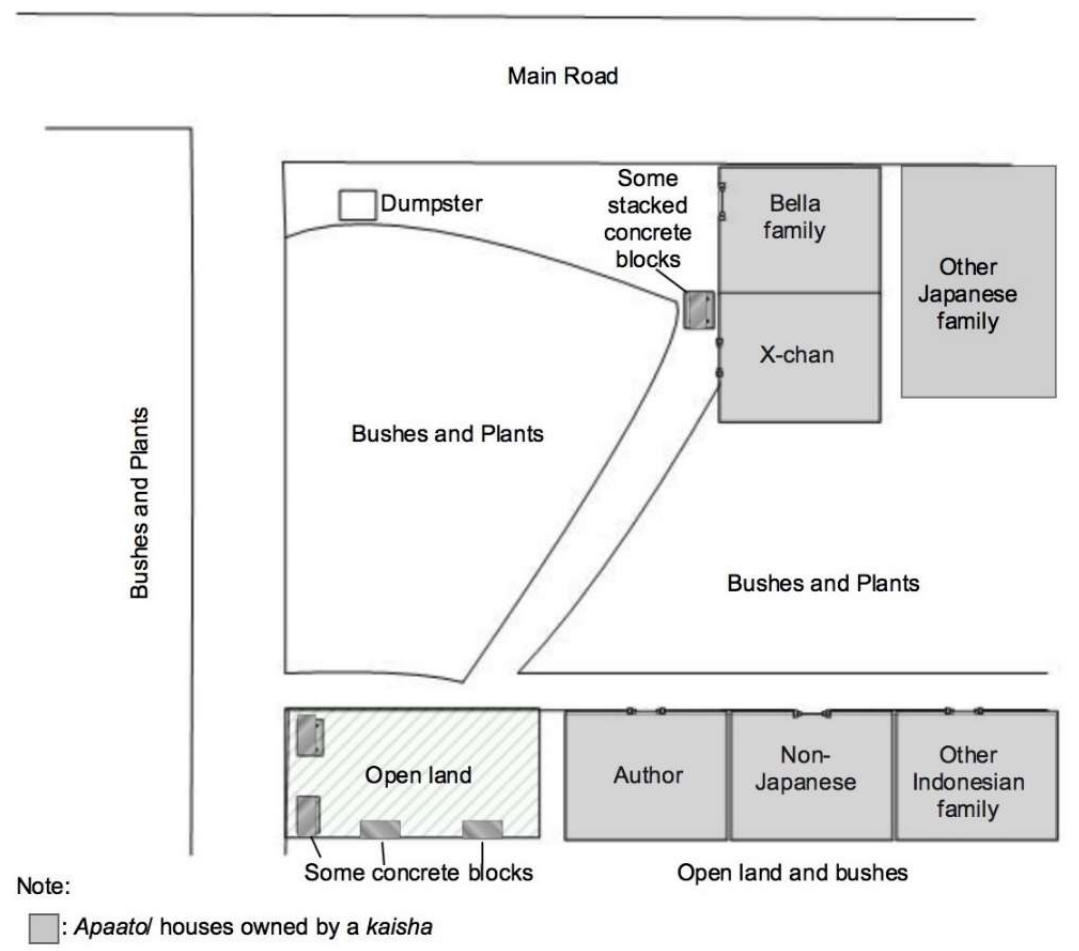

Figure 4. Illustrating map of the complex in the neighborhood (by author).

The day when I moved in, Karinda's husband drove me by car. He wanted to park at the side of my new house, and suddenly, his car wheels bumped into something: concrete blocks (not visible at

17 The previous tenants were an Indonesian family working in the kaisha, who lived there for seven years. They were overstaying migrants and were deported because their visa proposal was rejected in court. 
first). Although I could easily move them, I did not do so, as I had no clue what they were meant for. Later, I knew that it was X-chan who had put the concrete blocks there (see Figure 5). From Bella and the other participants, I knew that these concrete blocks were meant to prevent any Indonesian friends of the previous tenant of my apaato from parking their cars, or in other words, to visit. However, during my stay there, I observed that X-chan parked his car in the same place. Thus, as a first impression, although the houses are fenceless and relatively close to the neighbors, I felt a distance and discrimination from the neighbor.

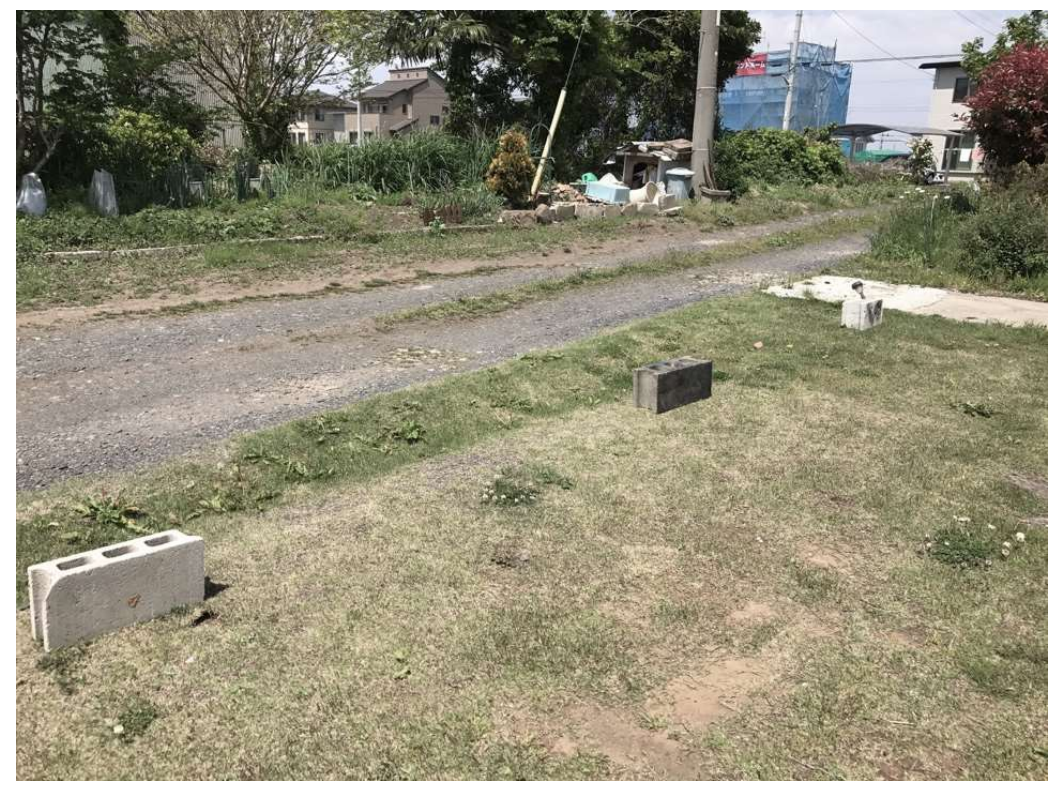

Figure 5. Some concrete blocks in front of the apartment where I lived.

The noise and complaints are not the only disturbance Bella experienced with the Japanese neighbor; he also put concrete blocks on the border between his house and Bella's house and forbids anyone but him from using the pathway (see Figure 4). Meanwhile, he can always go through the pathway when throwing garbage in the dumpster. My rented apaato ${ }^{18}$ is about $20 \mathrm{~m}$ from Bella's house, and I experienced trouble due to the concrete blocks. Although there is a shorter way from my rented house to Bella's, she warned me not to go through the pathway, but instead to go around through another road. The houses and land complex are owned by the shachou, not by the Japanese man, so he actually does not have any right to put hurdles or make unilateral rules for his neighbors, unless the shachou lets him do so.

When I met the owner of the house and a kaisha (I started calling him shachou after hearing everyone calling him that way), he suddenly warned me: "Please don't be noisy, especially after 9 p.m. You know, Indonesian people usually stay up 'til late, singing, playing guitar (while imitating a guitar-playing gesture). The person next door needs to sleep to work in the morning. Indonesian people are urusaii naa (noisy uh)." This warning struck me. Why would he think I would be noisy while I was alone? On the contrary, my next-door neighbor often invited his friends and played loud music until 3 a.m. When I tried to "report" to the owner, his response was just flat: "Oh, really", and then he ignored it. Although he was informed about my personal information and motivation for residing in Oarai, my identity (as a researcher) did not hinder him to think about my potential to be noisy and to neglect my noise report. I began to realize that it is because of my shared nationality and my engaging activities with the migrant workers.

18 The apaato is about $25 \mathrm{~m}^{2}$, with a kitchen, toilet, bathroom, washroom, and two bedrooms. 


\subsection{Dena: Dirt and Pebble-Throwing}

One-and-a-half kilometers from Bella's house, Dena parked her car in front of the alley to her rented house. That night, I was about to stay with her family. When we parked at the end of the pathway to her house, everyone whispered and moved silently. When her little daughter was cranky, she hushed harshly to make her silent. "Don't be urusaii, opa ${ }^{19}$ will be angry." Her daughter seemed used to this experience, and made a sudden nod signaling that she understood. Even when they entered the house, everyone kept silent in the doorway. The sound of their footsteps was muffled. That night (and every other night), even though they and I wanted to take a shower before sleeping, we could not do so because the neighbor would be angry about the noise. "There is an ojiisan (grandfather) in front (of the house) who usually throws stones at my front door if we make any noise", Dena whispered to me. I was surprised. Which ojiisan? I could only see a high wall in front of her house. It turned out that even having such a high wall and a side yard, the old Japanese man usually threw pebbles and dirt over the wall, specifically in front of the patio, yard, and doorway of Dena's house. On one occasion, she showed me some photos from her mobile phone of her dirty front door and front yard. One interesting photo shows how the shrubs along her house are green and healthy, except for on one side, exactly at the front side of her doorway opposite the old man's house. "We don't know what ojiisan throws, it may be sewage or poisonous water, so that ... look! (showing the photo); all the plants died only in that part (where he usually throws); the other plants are healthy", Dena explained. She also has one neighbor at the backside and next to her house who she said never complained, although their houses are not fenced off from Dena's house.

On that day, Dena also showed a video of her neighbor when coming and complaining to her house. I saw a Japanese man in his sixties bringing a long baseball bat and yelling at her husband. I could not clearly hear what they were saying, but the Japanese man looked intense and intimidating as he threatened Dena's husband with the bat. Instead of hitting Dena's husband, he asked Dena's husband to beat him first. Dena's husband shook his head as a sign that he was not going to do what he asked. Dena said to me that it was a trap for them, because this Japanese man only wanted to get rid of Dena's family by provoking Dena's husband to hit him, so he could report Dena's family to the authorities for committing a crime.

When I went to the police station in Oarai for some information regarding noise complaints and reports, the policeman I talked to explained that the police office had no records on those matters. The emergency line for contacting the police is commonly used for reporting crimes or accidents. Some other participants who had experienced being inspected by the police and immigration officers noted that the inspection happened after a neighbor reported them as having no valid visa (overstaying). Suspecting an invalid visa status seems to be the only way of reporting migrants when they do not commit any crime or make any proven disturbances.

\subsection{Karinda and the Cucumber}

Karinda lived in an old land house owned by the kaisha where she works, around six hundred meters from Dena's house. She and her family had only moved there in the past two years. The house has small side and back yards (each is approximately $1.2 \times 3 \mathrm{~m}$ ) and a fence in front of it. Compared to other participants' houses, I thought Karinda's house seemed to have more privacy.

I came to Karinda's house so we could go to the church together at 9 a.m. on a Sunday in October 2017. Suddenly, my conversation with her was interrupted by her neighbor shouting in front of her fence. She muttered: "oh, the urusaii oma", and then she went outside. From the living room's windows, I could hear that Karinda repeatedly said: "Hai, wakatta. Hai. Wakatta." (Yes, understood), while the neighbor kept talking continuously. After about $10 \mathrm{~min}$, she came back: "Oh, oma urusaii.

19 Opa (Bahasa Indonesian/Bahasa Manado) means grandfather. 
It's always difficult to interrupt her when talking. Wait a minute", she said to me, and suddenly asked her husband to cut off all the cucumbers that they had planted in the back yard. It turned out that her neighbor blamed the cucumbers Karinda had planted for influencing the health of the plum tree in the back yard. Karinda's husband asked: "Now? But we are going to go." Karinda asked him to cut them now because the oma had been demanding the cucumbers to be cut off as soon as possible. She also blamed all plants in the pots that Karinda and her husband planted along their side yard. "She blamed everything we planted. She said the minerals in the soil are decreasing because we grow plants here." Karinda's husband took shovels and garden scissors and added, "Actually her ume (plum) is not thriving because she never puts fertilizer on it. It is not because of our cucumbers." However, Karinda just calmed down her husband and got him to do what the neighbor said.

It turns out that although Karinda rents the house, the two trees (orange and plum) in the back yard are claimed to be owned by the oma, the neighbor, who is also the mother of the owner of the house and kaisha where she works. She lives in a house opposite Karinda's rented house. Karinda had to accept the terms when the shachou offered to rent her the house, being that the shachou's mother owns the trees in the backyard. In consequence, the shachou's mother could have the right to enter the back yard through the side of the house. This is why, although Karinda's house is fenced, that fence is never locked.

\subsection{Leo and Neighbors' Rejection}

Around $800 \mathrm{~m}$ from Karinda's house, I talked to Leo in his apaato in February 2016. Leo was very open, friendly, and spoke a lot during our talk in his living room after he came home from work. We talked near the heater, which was turned on to warm up the cold evening. His youngest son was playing around him cheerfully. Leo is one of the most trusted workers in the shop he works at. He even had appeared on TV once when there were artists coming to Oarai, as the shop he works at is one of the most famous places to eat fresh seafood. He is always the one assigned by the shop manager (tenchou) to serve the special guests. Nevertheless, when I asked Leo what the biggest hurdle was about living in Japan so far, his tone changed; his gaze was on his son, but was empty. I could feel agitation and despair. He sounded desperate, which surprised me after our exuberant talk:

"If here, with the people is not good, it is difficult."

"Neighbors?" I asked. He did not answer and just continued his story.

"It has been 10 years. If they are not willing to [accept] us, if they hate foreigners, they will hate them until ... (trails off) ... that kind of characters exist. If they are, from the first time hate foreigners, it is impossible to change it, even if we give them anything, they will not like us. Some people are open, but some people are difficult. Even though we don't disturb them, they won't change it. From the past, this place (the apaato) has been the place of foreigners. So, they can't accept it."

He continued with low tones. I continued to feel his painful rejection. "What's the example?" I asked.

“Well ... (sighs) If we usually say good morning or anything else ... they just ignored it. But that was only a standard of people run across, right? Aisatsu (greetings). But, because from the first time ... (he pauses) There was one occasion, at that time, I was walking, and he suddenly drove back his car carelessly, with an intention to hit me! It means ... it seems [they] don't like us. [As] it has been from the first impression, not good, [it will not be good] forever and ever. If they could accept us, we should have been close. [ . . ] If he doesn't care, perpetually, he won't care to us. That is [how] Japanese [are]. If they care, wherever we are ... 'ah, we've met.' [showing intimacy] like that." 
Neighbor relations could be the most mundane of relationships that occur in the small routines of social life, for example, as we say 'good morning' whilst walking to the car (Stokoe and Wallwork 2003), as expected by Leo as standard greetings. For a person like Leo, who is friendly and wants to initiate connections with people, this kind of rejection hurts. Neighbors are the closest people migrants can encounter while being far from their families.

\section{Discussion}

\section{1. 'Noise': the Unwanted Body}

In the case of the five participants, even if their presence is not visible or seen, even if the actual noise is not heard, Japanese neighbors feel and perceive migrants' bodily presence as loud 'noise'. This is explainable by a concept offered by a French philosopher, Nancy (1992) that "bodies resonate tension" (in Schulze 2012, p. 202). This tension "trembles" through the bodies of neighbors "as a tone" (Schulze 2012, p. 203). The foreignness of the body resembles the newness of the sound, which is then perceived as noise (see Figure 6). However, it needs to be underlined that this concept of 'the body as sound' is different to 'sounds of the body' or 'body as the source of noise', in which the two latter include the sounds of body parts or organs. A body is "a kind of space or container, which consists of many entities: mind, soul, words, emotions, thoughts, and so on" (Skara 2004, p. 185). "The body as sound' means the bodily presence (of a migrant) resembling the sound's presence, as it also includes high information content of cultural embeddedness, felt as tension.

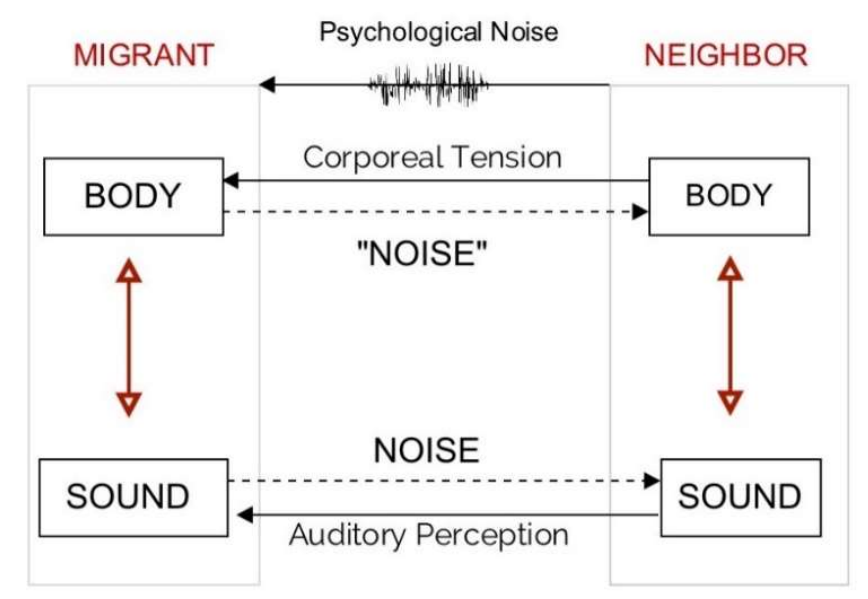

Figure 6. Conceptual framework of noise by the actual sound and 'noise' by the corporeal tension.

The 'body' in the metaphorical sense of 'noise', which is substitutable to sound, has the characteristic of being unwanted, as in the same projection to bodily presence. Adopting the concept of this bodily presence by Nancy $(1992,2000)$, I want to stress that 'noise' in the case of five participants, which is construed through a bodily felt sense rather than by an auditory sense, results in a corporeal tension which is not a 'mere' mental or 'only' emotional state, but a corporeal state (Nancy 2000 in Schulze 2018, p. 204). From this proposition, espousing from Deleuze and Guattari (1991) the concept of a percept, I argue that the presence, which could include the sound, the smell, and even the motion of the migrants' bodies propagates and extends its particular energy into the corporeal area of some of their neighbors. Thus, even if the migrants are not actually seen or heard, the tension is felt by the bodies of Japanese neighbors and perceived as 'noise'. This metaphorical sense of noise, as it is felt from the bodily presence of migrants, is grounded in a physical, sensory, and corporeal experience (Schulze 2018). Noise as a result of the projection of the body attribution as foreign beings, is perceived with or without the presence of visual e.g., Priscilla's and Dena's houses are on the back of the neighbors' house, or with or without auditory aspects at all; e.g., Karinda's cucumbers, Leo's presence, and Bella's inexistent new year's party. The metaphorical sense of 'noise' here seems to 
be identical with the ontological noise explained by Hainge, in that it indexes the resistance that accompanies any act of expression and it cannot be heard as such in ontic noise (Hainge 2013), which deserves to be discussed further in the next studies.

'Noise' perceived from the tension of unwanted bodily presence is embodied in migrants as byproducts of the psychological noise of the hearers. This 'noise' is a result of psychological noise in turn resulting from preconceived notions, such as racial stereotypes, reputations, biases, and assumptions (Rothwell 2004). Psychological noise, such as stress and anger, interfere primarily with the cognitive processes of listening (Jones 2013) in the interaction and communication between a migrant and neighbor. Hence, migrant and neighbor relations can be seen as communication where there is some noise influencing how they transfer messages through the pathways of communication (channels). Typically, channels represent our visual, tactile, olfactory, and auditory senses (Jones 2013). In the case of the migrants, their channels of communication with their neighbors before the first noise complaints occurred were only visual and auditory, with minimal contact. The direct visual encounter is, for example, meeting around the neighborhood or the workplace (kaisha). The direct and nondirect auditory experiences are, for example, the sound of daily activities in their houses, where this sound may intrude through the shared or thin walls, and around the neighborhood, including speaking, respectively. The actual noises can also be merely in an auditory sense, such as talking in a foreign language, daily home activities, the sound of footsteps, sound of children crying, voices in a foreign language, and so on. At the same time, in the perspectives of migrants, these Japanese neighbors are also urusaii (noisy) for making constant unreasonable complaints and reporting escalating conflicts.

\subsection{Noise Conflicts: Social Power Over Space}

The stories demonstrate some conflicts regarding noise and coexistence between migrants and neighbors in a compact town such as Oarai. There is a tendency for migrants to make compromises in regard to all complaints and to want to understand and initiate neighborhood ties; i.e., to integrate. In Oarai, people work in the same neighborhoods where they live. Their neighbors can be their work partners or those who have close relations with the owners of where migrants live and work. The oma who asked Karinda to cut the cucumbers is the shachou's mother. The Japanese man living next to Bella's is the shachou's trusted person at the kaisha; the ojiisan's wife who throws pebbles and dirt at Dena's front door is the senior worker at the same kaisha with Dena and her family. Additionally, the owners of the houses or apaato the migrants live in are always the same people who own the kaisha in which they work. These overlapping positions at the workplace and as neighbors explain the power imbalance. The objectivation of the opposition between the dominant and dominated positions in the neighborhood is clear-cut and speaks volumes about the ways the dominant class mobilizes in defense of its interests (Pinçon-charlot and Pinçon 2018).

Moreover, the noise reports and space control are escalated through the act of the Japanese neighbors themselves or through the third parties, such as the kaisha or the authorities (see Figure 7). The mass arrest in 2002 of overstaying migrants in Oarai is one of the examples of neighbors reporting to the authorities about noise disturbances rather than because of visa issues. In the recent decade, most of the migrants living in Oarai are Japanese descendants with valid visa status; however, threats, space control, and prejudice by Japanese neighbors persist. The Japanese neighbors' actions-putting stones in public places to prevent migrants from moving freely, throwing dirt in the private outdoor space (POS) of others, claiming trees inside another's garden, writing and putting a sign by the entrance door where Priscilla and her family live-indicate the establishment of boundaries and power to control private-public spaces. This domination and control of private-public spaces escalate to boundary-making and arbitrary rules set by the Japanese neighbors without conventions. Being native residents, they have the means to translate "social distances into spatial distances" (Pinçon-charlot and Pinçon 2018, p. 119), which results in the double process of segregation and aggregation ${ }^{20}$.

20 As addressed by Bourdieu (1993) in a chapter in La Misère du Monde. 


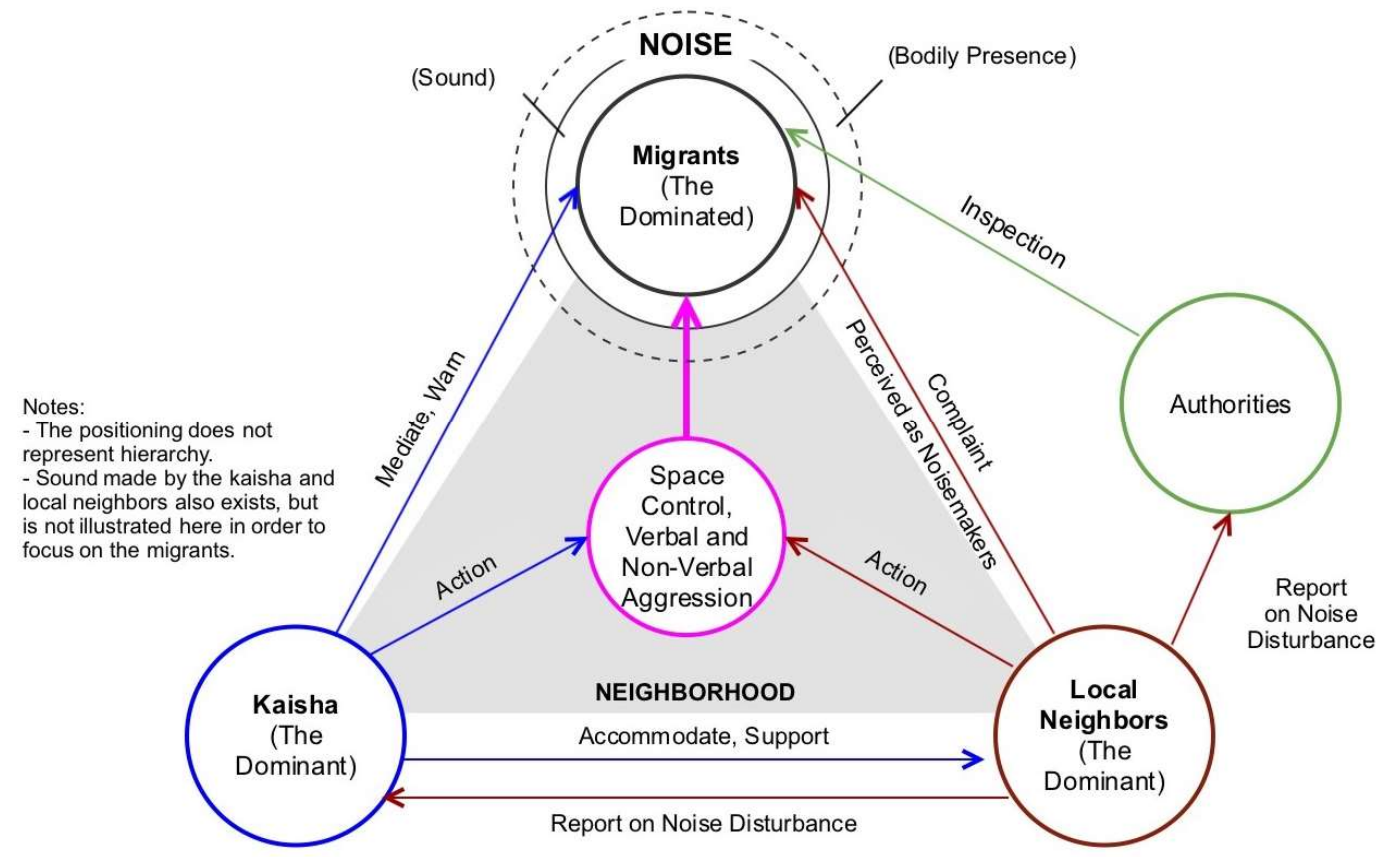

Figure 7. Noise conflict escalations in Oarai.

Noise is what people perceive from the sound we produce, and even from our bodily presence. Whether people decide to make a complaint about the perceived noise depends on their social power and domination. Thus, the 'act of complaining' becomes the privilege of the dominant. Although the migrants sometimes felt that their neighbors were noisy, they did not complain for at least two reasons: they did not know how to make a complaint and defend it (because of linguistic and social powerlessness) and they did not think it would be useful because of their lack of power. Most of the time, the dominated is cornered into compromising and apologizing rather than voice their own complaint about the repetitive unreasonable complaints of the dominant. This domination results in a one-way direction of complaining, and the complaint-receivers are always to blame (referring to the common terms between noise victims and noise perpetrators). In short, noise conflict is primarily about whether the 'you' (who affects) and 'me' (who is affected) are satisfied with a social relationship of the perceived control over the noise that "you expose me to!" present in all sorts of socially or power-related exchanges taking place (Van Gunsteren 1999, p. 4). Thus, noise-complaint-making and noise hearing are separate events (as also depicted in Figure 1).

Remarkably, engaging to participants' life stories was like riding a rollercoaster, with the emotional mixtures of their unforgettable moments, their despairs, and agitations. I sensed their feeling of 'home' in Oarai, in having stronger communities and networks, with the growth of their ethnic churches and the reunion of more family members. However, I also noticed and felt the changing of emotions when they started talking about their neighbors (for example, in Bella and Leo's narratives). Their tone, facial expression, and gaze were altered as they started talking about the 'urusaii' (noisy) neighbors who become 'mondai' (problems) for them. These two words are frequently used by them to express their emotions regarding their neighbors. Through my sensory experiences as a migrant living in the neighborhood, I also felt the stigma of being a gaijin and a noisemaker, which is "deeply discrediting" (Goffman 1963, p. 3). For the participants, it is not a mere attribution; it has also become embedded in their social relations with their neighbors for two decades. Through the participants' emotional shifts, I understood that the Japanese neighbors' continuous unreasonable complaints have become another 'noise' in the migrants' ongoing process of cultivating a home in Japan, about which they cannot complain. 


\section{Conclusions}

Noise is what people perceive from the sounds we produce, and even from our bodily presence. Noise perceived by the local neighbors ${ }^{21}$ who feel disturbed by the presence of the migrants is both concrete and abstract. The foreignness of the body, resembling the newness of the sounds of migrants, is perceived as 'noise', which is the perception of the listeners of the unwanted bodily presence of migrants, similar to perceiving noise as unwanted sound. 'Noise', in this concept, is embodied in migrants as a byproduct of the psychological noise which resonates corporeal tension of the hearers. This 'noise' is perceived as a result of the projection of the bodily attribution as being foreign, with or without any presence of visual or auditory aspects. Whether people decide to make complaints about the perceived noise depends on their social power and domination.

In a rural area such as Oarai, land is compact, houses are borderless, and walls are thin. Migrants and neighbors can meet, hear, and easily sense each other's presence. The communication from Japanese neighbors to migrants is conducted through continuous complaints, reports, and bordering, which signify how distinction and separation are imagined, where private and public spaces are contested. The partition of stones or wires provides an obvious example of a boundary marker that is unlikely to produce good neighborly relations (Nash 2009). As migrants work in the same neighborhoods as where they live, their relations with neighbors are layered with imbrications of unequal social and power structures between the roles of neighbors, workers, and migrants with the stigma of 'gaijin' and noisemakers from the past overstaying migrants. Beyond neighbor relations in negotiating private-public spaces, the phenomena of noisemaking and noise complaints in Oarai rendered less control to migrants over their private lives and spaces in personalizing their homes.

Home itself is a "second skin" (Serres 1985, p. 147) for human beings, and domestic and private space is vital to generating meaning and a sense of self and belonging. Hence, it is crucial for migrants to be able to create a place for themselves that is a safe haven from the public realm (Mee 2007, p. 28). However, although the home is where domesticity becomes private, Indonesian migrants in Oarai must negotiate being attributed as 'noisemakers' when making private sounds or no sound at all at home. More often, they can only compromise in managing noise complaints from their neighbors because of their power limitations. Thus, Japanese neighbors' continuous unreasonable complaints are 'urusaii' (noisy) and become 'mondai' (problems) for migrants in their ongoing process of 'home-making' in Japan. Finally, this research on migrants as 'noisemakers' suggest that noise complaints disproportionately affect the weak (Keizer 2010), who are dominated and blamed for noise and who have less power to protest or move away from the difficult situations.

Funding: The fieldwork was funded by Fuji Xerox, Co. Ltd., Foreign Students Research Grant No. 897.

Acknowledgments: I am extremely grateful to all research participants in Oarai who have generously shared their time to participate in this study and who have accepted me in their community regardless of my different religious and ethnic backgrounds.

Conflicts of Interest: The author declares no conflict of interest. The funders had no role in the design of the study; in the collection, analyses, or interpretation of data; in the writing of the manuscript; or in the decision to publish the results.

\section{References}

Alesina, Alberto, and Eliana La Ferrara. 2002. Who Trusts Others? Journal of Public Economics 85: 207-34. [CrossRef] Aletta, Francesco, Timothy van Renterghem, and Dick Botteldooren. 2018. Influence of Personal Factors on Sound Perception and Overall Experience in Urban Green Areas. A Case Study of a Cycling Path Highly Exposed to Road Traffic Noise. International Journal of Environmental Research and Public Health 15: 1118. [CrossRef] [PubMed]

21 Because of some limitations, this study could not attempt to seek the perspective of the Japanese neighbors. This would be recommended for future research. 
Appleyard, Donald, and Mark Lintell. 1971. Environmental quality of city streets: the residents' viewpoint. Journal of the American Institute of Planners 38: 84-101. [CrossRef]

Augoyard, Jean-François, and Henri Torgue. 2005. Sonic Experience. A Guide to Everyday Sounds. Edited and Translated by Andra McCartney and David Paquette. Montreal and Kingston: McGill-Queen's University Press.

Bourdieu, Pierre. 1993. Effets de lieux [Site effects]. In La misère du monde. Edited by Pierre Bourdieu. Seuil and Paris: Polity Press, English Translation. 1999. As The Weight of the World. Cambridge: Polity.

Broadbent, Donald Eric, and E. A. J. Little. 1960. Effects of noise reduction in a work situation. Occupational Psychology 34: 133-40.

Bronzaft, Arline, and Gregg van Ryzin. 2004. Neighborhood Noise and its Consequences. Special Report \#3. New York: School of Public Affairs, Baruch College/CUNY, New York: eTownPanel.com.

Chen, Xinguang, Bonita Stanton, Linda Kaljee, Xiaoyi Fang, Qing Xiong, Danhua Lin, Liying Zhang, and Xiaoming Chen. 2011. Social stigma, social capital reconstruction, and rural migrants in urban China: A population health perspective. Human Organization 70: 22-32. [CrossRef] [PubMed]

Danson, Mike, and Birgit Jentch. 2012. International migration and economic participation in small towns and rural areas-cross-national evidence. Migration Letters 9: 215-24. [CrossRef]

De Carvalho, Daniela. 2003. Nikkei communities in Japan. In Global Japan: The Experience of Japan's New Immigrant and Overseas Communities. Edited by Roger Goodman, Ceri Peach, Ayumi Takenaka and Paul White. London: RoutledgeCurzon, pp. 195-208.

De Lima, Philomena. 2012. Boundary Crossings: Migration, Belonging/'Un-belonging' in Rural Scotland. In Translocal Ruralism: Mobility and Connectivity in European Rural Spaces. GeoJurnal Library. Edited by Charlotta Hedberg and Renato Miguel do Carmo. Dordrecht: Springer, vol. 103, pp. 203-17.

De Lima, Philomena, and Sharon Wright. 2009. Welcoming migrants? Migrant labour in rural Scotland. Social Policy and Society 8: 391-404. [CrossRef]

Deleuze, Gilles, and Félix Guattari. 1991. Qu'est-ce que la philosophie? Paris: Les Editions de Minuit, Translated by Graham Burchell, and Hugh Tomlinson. 1994. As What Is Philosophy? New York: Columbio University Press.

Dolan, Daniel. 2008. Cultural Noise: Amplified Sound, Freedom of Expression and Privacy Rights in Japan. International Journal of Communication 2: 662-90.

Gendlin, Eugene T. 1992. The Wider Role of Bodily Snese in Thought and Language. In Giving the Body Its Due. Edited by Maxine Sheets-Johnstone. Albany: SUNY Press, pp. 192-207.

Gloag, Daphne. 1980. Noise and health: Public and private responsibility. British Medical Journal 281: 1404-6. [CrossRef]

Goffman, Ervin. 1963. Stigma. Englewood Cliffs: Prentice-Hall.

Goffman, Ervin. 2001. On fieldwork. In Contemporary Field Research. Edited by Robert M. Emerson. Prospect Heights: Waveland Press, vol. 24, pp. 623-50.

Gurney, Craig. 2000. Transgressing Private-Public Boundaries in the Home: A Sociological Analysis of the Coital Noise Taboo. Venereology 13: 39-46.

Hainge, Greg. 2013. Noise Matters: Towards an Ontology of Noise. New York: Bloomsbury Academic.

Hankins, Joseph D. 2014. Publics that scream, publics that slumber. In Sound, Space and Sociality in Modern Japan. Edited by Joseph D. Hankins and Carolyn S. Stevens. London and New York: Routledge.

Hiramatsu, Kozo. 1993. Some aspects of soundscape studies in Japan. Journal of the Acoustical Society of Japan 14: 133-38. [CrossRef]

Honda, Hideomi, and Seiichiro Ono. 2000. Aji Himono Gohatsu Sanchi Oarai no Taito. Chiiki Gyogyo Kenkyu 40: 141-53.

Janssen, Sabine A., and Henk Vos. 2011. A comparison between exposure-response relationships for wind turbine annoyance and annoyance due to other noise sources. The Journal of the Acoustical Society of America 130: 3746-53. [CrossRef] [PubMed]

Johnson, Kristen Linnea, and Michael Elwood Roloff. 2000. Correlates of the Perceived Resolvability and Relational Consequences of Serial Arguing in Dating Relationships: Argumentative Features and the Use of Coping Strategies. Journal of Social and Personal Relationships 17: 677-78. [CrossRef]

Jones, Richard G., Jr. 2013. Communication in the Real World: An Introduction to Communication Studies. Irvington: Flat World Knowledge. 
Jones, Dylan M., Antony J. Chapman, and Timothy C. Auburn. 1981. Noise in the Environment: A Social Perspective. Journal of Environmental Psychology 1: 43-59. [CrossRef]

Keizer, Garret. 2010. The Unwanted Sound of Everything We Want: A Book About Noise. New York: Public Affairs.

Krieger, Daniel. 2014. Making noise about keeping the decibels down. The Japan Times. October 10. Available online: https://www.japantimes.co.jp/life/2014/10/10/lifestyle/making-noise-keeping-decibels/\#. W8GvZLaB1mA (accessed on 1 October 2018).

Levy-Leboyer, Claude, and Veronique Naturel. 1991. Neighborhood Noise Annoyance. Journal of Environmental Psychology 11: 75-86. [CrossRef]

Lindsay, Morag, Katie Williams, and Carol Dair. 2010. Is There Room for Privacy in the Compact City? Built Environment 36: 28-46. [CrossRef]

Linger, Daniel Touro. 2001. No One Home: Brazilian Selves Remade in Japan. Stanford: Stanford University Press.

Mazumi, Yusuke. 2014. How Does Labor Migration Occur in Japan?: Policy and Labor Demand in the Seafood Processing Industry. Ph.D. dissertation, University of California, San Diego, CA, USA.

McKennell, Aubrey. 1963. Aircraft Noise Annoyance around Heathrow Airport. London: Her Majesty's Stationary Office.

Mee, Katleen. 2007. “I Ain't Been to Heaven Yet? Living Here, This is Heaven to Me": Public Housing and the Making of Home in Inner Newcastle. Housing, Theory and Society 24: 207-28. [CrossRef]

Meguro, Ushio. 2005. Establishment of the Japanese-Indonesian Community and their Employment System in the Oarai Town, Ibaraki. I bunka komyunikēshon kenkyū 17.

Meguro, Ushio. 2010. Social Capital and Job-Searching Processes of Japanese-Minahasans in Oarai, Ibaraki Prefecture, Japan. Geographical Review of Japan Series B (The Association of Japanese Geographers) 82: 167-83.

Mutiara, Median. 2018. Managing Boundaries between (Dirty) Work and Church Life for Indonesian Migrant Workers in Japan. IAFOR Journal of Cultural Studies 3: 43-63. [CrossRef]

Nancy, Jean-Luc. 1992. Corpus. Paris: Editions Métailié.

Nancy, Jean-Luc. 2000. Being Singular Plural. Stanford: Stanford University Press.

Nash, Lindsay. 2009. Mending Wall: Playing the Game of Neighborhood Ordering. Yale Journal of Law E the Humanities (Yale Law School Legal Scholarship Repository) 21: 173-201.

Niemann, Hildegard, Xavier Bonnefoy, Matthias Braubach, Karl Hecht, Christian Maschke, C. Rodrigues, and Nathalie Robbel. 2006. Noise-induced annoyance and morbidity results from the pan- European LARES study. Noise \& Health 8: 63-79.

Oku Okokon, Enembe, Anu W. Turunen, S Ung-Lanki, Anna-Kaisa Vartiainen, Pekka Tiittanen, Timo Lanki, Peter Lercher, Ronny Klaeboe, and Mariola Śliwińska-Kowalska. 2015. Road-Traffic Noise: Annoyance, Risk Perception, and Noise Sensitivity in the Finnish Adult Population. International Journal of Environment Research and Public Health 12: 5712-34. [CrossRef]

Park, Sang Hee, and Pyoung Jik Lee. 2017. Effects of floor impact noise on people-Annoyance and physiological responses. Paper presented at 12th ICBEN Congress on Noise as a Public Health Problem, Zurich, Switzerland, June 18-22.

Petersen, Sandra Lori. 2016. Noise, Social Housing and Sleep: A Social Science Review. København: University of Copenhagen.

Pinçon-charlot, Monique, and Michel Pinçon. 2018. Social Power and Power Over Space: How the Bourgeoisie Reproduces Itself in the City. International Journal of Urban and Regional Research 42: 115-25. [CrossRef]

Plourde, Lorraine. 2014. Distraction, noise, and ambient sounds in Tokyo. In Sound, Space and Sociality in Modern Japan. Edited by Joseph D. Hankins and Carolyn S. Stevens. London and New York: Routledge, pp. 71-88.

Pudjiastuti, Tri Nuke. 2005. The Dynamics of Indonesian Migrant Workers under National and Local Policies: The Oarai Case. I bunka komyunikēshon kenkyū 17: 79-104.

Pugh, Richard. 2007. New Migrants and Minorities: Understanding Difference and Discrimination in Rural Areas. Paper distributed at the Conference 'International Migration and Rural Areas: Global Perspectives, Isle of Skye, Scotland, UK, 11-12 October.

Ricke, Audrey. 2017. Making "Sense" of Identity: Ethnicity, Nationalism, and the Sensory Experience of German Traditions in Brazil. Journal of Contemporary Ethnography 46: 173-202. [CrossRef]

Rivera, Kendra Dyanne, and Sarah J. Tracy. 2014. Embodying emotional dirty work: A messy text of patrolling the border. Qualitative Research in Organizations and Management: An International Journal 9: 201-22. [CrossRef] 
Roberts, Kenneth D. 2002. Rural migrants in urban China: Willing workers, invisible residents. Asia Pacific Business Review 8: 141-58. [CrossRef]

Rothwell, Dan J. 2004. In the Company of Others: An Introduction to Communication. New York: McGraw Hill. Schulze, Holger. 2012. The body of sound: Sounding out the history of science. Sound Effects 2: 198-209. Schulze, Holger. 2018. The Sonic Persona: An Anthropology of Sound. New York and London: Bloomsbury. Serres, Michel. 1985. Philosophie des corps meles: Les Cinq Sens. Paris: Editions Gallimard.

Shin, Hwaji. 2010. Colonial legacy of ethno-racial inequality in Japan. Theory and Society 39: 327-42. [CrossRef]

Skara, Danica. 2004. Body Metaphors-Reading the Body in Contemporary Culture. Collegium Antropologicum 28 S1: 183-89.

Smith, Andrew P. 2003. The Concept of Noise Sensitivity: Implications for Noise Control. Noise E Health 5: 57-59. Stokoe, Elizabeth. 2003. Mothers, Single Women and Sluts: Gender, Morality and Membership Categorization in Neighbour Disputes. Feminism and Psychology 13: 317-44. [CrossRef]

Stokoe, Elizabeth. 2006. Public Intimacy in Neighbour Relationships and Complaints. Sociological Research Online 11: 2-20. [CrossRef]

Stokoe, Elizabeth, and Alexa Hepburn. 2005. 'You can hear a lot through the walls': Noise formulations in neighbour complaints. Discourse \& Society 16: 647-73.

Stokoe, Elizabeth H., and Jodi Wallwork. 2003. Space Invaders: The moral-spatial order in neighbour dispute discourse. British Journal of Social Psychology 42: 551-69. [CrossRef]

Sugino, Toshiko. 2008. Nikkei Brazilians at a Brazilian School in Japan. Tokyo: Keio University Press.

Sumakul, Henny WIlliam Booth. 2005. The Concept of Vocation Amongst Migrant Workers of the GMIM (Christian Evangelical Church in Minahasa) in Postmodern Times. Ph.D. dissertation, Faculty of Theology, University of the Free State, Bloemfontein, South Africa.

Sunderland, Naomi, Helen Bristed, Ori Gudes, Jennifer Boddy, and M. Da Silva. 2012. What does it feel like to live here? Exploring sensory ethnography as a collaborative methodology for investigating social determinants of health in place. Health $\mathcal{E}$ Place 18: 1056-67.

Tarnopolsky, Alex, S. M. Barker, R. D. Wiggins, and E. K. McLean. 1978. The effect of aircraft noise on the mental health of a community sample: A pilot study. Psychological Medicine 8: 219-33. [CrossRef]

Tirtosudarmo, Riwanto. 2005. The Making of a Minahasan Community in Oarai: Preliminary Research on Social Institutions of Indonesian Migrant Workers in Japan. I bunka komyunikēshon kenkyū 17: 105-38.

Tsuda, Takeyuki. 1999. The Permanence of "Temporary" Migration: The "Structural Embeddedness" of Japanese Brazilian Immigrant Workers in Japan. The Journal of Asian Studies (Association for Asian Studies). 58: 687-722. [CrossRef]

Tsuda, Takeyuki. 2000. Migration and Alienation: Japanese-Brazilian Return Migrants and the Search for Homeland Abroad. Available online: http:/ / www.bristol.ac.uk/ (accessed on 25 May 2018).

Tsuda, Takeyuki. 2003. Stranger in the Ethnic Homeland: Japanese Brazilian Return Migration in Transnational Perspective. New York: Columbia University Press.

United Nations Department of Economic and Social Affairs. 2018. Prejudice and Discrimination: Barriers to Social Inclusion. Social Development Brief \#4. New York: Division for Social Policy and Development, UNDESA, United Nations Department of Economic and Social Affairs.

Van Gunsteren, Herman R. 1999. When noise becomes too much noise. Noise E Health 3: 3-5.

Van Kamp, Irene, Raymond Soames Job, Julie Hatfield, Mary Haines, Rebecca K Stellato, and Stephen A Stansfeld. 2004. The role of noise sensitivity in the noise-response relation: A comparison of three international airport studies. The Journal of the Acoustical Society of America 116: 3471-79. [CrossRef] [PubMed]

Weinhold, Diana. 2015. Sick of Noise: The Health Effects of Loud Neighbours and Urban Din. Working Paper No. 213. Grantham Research Institute on Climate Change and the Environment. Available online: http:/ / www.lse.ac.uk/GranthamInstitute/publication/sick-of-noise-the-health-effects-of-loudneighbours-and-urban-din/ (accessed on 26 June 2018).

(C) 2018 by the author. Licensee MDPI, Basel, Switzerland. This article is an open access article distributed under the terms and conditions of the Creative Commons Attribution (CC BY) license (http:/ / creativecommons.org/licenses/by/4.0/). 